\title{
Considerações sobre o trabalho com o júri simulado em uma questão sociocientífica com futuros professores de física
}

Adenilson Francisco Tetzener Junior

adenilson.junior.qm@gmail.com 0000-0001-7177-4482

Universidade Federal de São Carlos,

Araras, São Paulo, Brasil.

Nataly Carvalho Lopes

natalylopes@cca.ufscar.br

0000-0002-5113-8398

Universidade Federal de São Carlos,

Araras, São Paulo, Brasil.

\section{Augusto Higor do Santos de} Abreu

abreudeaugusto@hotmail.com 0000-0002-1799-5070

Universidade Federal de São Carlos,

Araras, São Paulo, Brasil.

Daniel Brina

daniel brina@yahoo.com.br 0000-0002-6032-4221

Universidade Federal de São Carlos,

Araras, São Paulo, Brasil.

Higor Gustavo Pires

higorpires@outlook.com

0000-0002-9624-1022

Universidade Federal de São Carlos,

Araras, São Paulo, Brasil.

Rafael Pereira da Silva

rafahpj@gmail.com

0000-0003-2623-4596

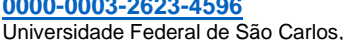

Araras, São Paulo, Brasil.

Cristiano Rocha de Oliveira cristianorocha@folha.com.br 0000-0003-4139-6710

Universidade Federal de São Carlos, Araras, São Paulo, Brasil.

\begin{abstract}
RESUMO
Compreendemos e interpretamos o trabalho realizado durante um júri simulado sobre uma questão sociocientífica (QSC) nas aulas de metodologia de ensino de um curso de licenciatura em física em uma Instituição Federal de Ensino Superior (IFES), uma vez que ainda é importante conhecer como práticas desta natureza podem ser potenciais para a formação e atuação de futuros professores. As questões sociocientíficas estiveram ligadas à implementação de uma nova fonte de energia elétrica na cidade fictícia de Tranquilina do Sul, cujos aspectos de ciência, tecnologia, sociedade, ambiente e ética tornavam a questão controversa. $\mathrm{O}$ júri simulado teve como base o jogo de papéis entre os atores responsáveis pelas diferentes fontes de energia propostas e representantes da sociedade, além da mediação da professora da turma que conduziu a discussão para a escolha de uma destas fontes. Também conduzimos do trabalho com a intensão de registrar os dados, a partir dos quais pudemos realizar análises e interpretações e propor discussões e inferências sobre as potencialidades desta prática para a formação de professores e para o ensino de ciências. Ao final, pudemos compreender a importância do trabalho que abrangeu conceitos científicos, tecnológicos, ambientais e sociais que caracterizam o tema como sociocientífico.
\end{abstract}

PALAVRAS-CHAVE: CTS. Energia. Jogo de papéis. Ensino de ciências. Ensino de física. Formação de professores. 


\section{INTRODUÇÃO}

Quais os aspectos formativos da experiência com júri simulado nas aulas de metodologia de ensino na formação inicial de professores de física? Esta foi a questão que nos motivou a interpretar a situação que criamos numa das aulas de metodologia de ensino para a licenciatura em física de uma IFES, na qual futuros professores e a docente responsável pela disciplina puderam desenvolver esta prática, com o objetivo de discutir sobre as potencialidades e limitações de práticas de ensino de acordo com as questões sociocientíficas (QSC). Além disso, esperamos contribuir com discussões importantes para o avanço da pesquisa na área, que tem urgência na exploração de experiências efetivas com as QSC em sala de aula, tanto na educação básica quanto na formação docente.

De acordo com Pèrez e Carvalho (2012), o trabalho com as QSC na formação de professores possibilita o desenvolvimento do pensamento crítico e da formação para a tomada de decisões nas esferas públicas, quando os assuntos discutidos levam em consideração o conhecimento científico, o tecnológico, os conhecimentos éticos e morais, além de questões ambientais, sociais, econômicas e políticas, elementos que adicionados às controvérsias destes temas, constituem as questões sociocientíficas. Tais discussões apontam para objetivos importantes da educação em ciências, que são aqueles que direcionam o trabalho do professor para formar agentes que são capazes de reconhecer as questões controversas que envolvem ciência e tecnologia, cuja população, em sua maioria, apenas vivencia os resultados das deliberações realizadas em esferas mais amplas e distantes da participação pública. Além disso, esta compreensão também possibilitaria que os agentes pudessem influenciar e modificar estas decisões, de modo a melhorar a qualidade de vida da população.

Estas questões estão presentes na vida cotidiana e podem ser acessadas pelos diversos meios de comunicação, que por vezes, apresentam discussões voltadas aos interesses de poucos e comprometidos apenas com os aspectos econômicos, em detrimento dos ambientais, éticos e sociais. Exemplos da América Latina e do Brasil são a exploração das monoculturas, como a cana-de-açúcar, soja, milho e eucalipto, que têm o selo da sustentabilidade, mas que apresentam impactos ambientais e sociais graves, como a constatação de trabalho escravo ou semiescravo, enfraquecimento do solo que acarreta processos de desertificação, os problemas com agrotóxicos e sementes transgênicas, além de não sanar emergências sociais, como a fome e o desenvolvimento científico, tecnológico, econômico e social dos países ainda não desenvolvidos. Também são exemplos de QSC os desastres ambientais de Mariana e Brumadinho - MG, cujas perícias técnicas constataram a responsabilidade da empresa exploradora; a construção da barragem de Belo Monte, o impedimento da atuação da empresa Monsanto no México, a exploração de gás natural em áreas de preservação ambiental na Bolívia, entre tantas outras QSC que são veiculadas ou silenciadas pela mídia diariamente. Exemplo mais atual de QSC são as controvérsias que envolvem a pandemia de COVID-19, que no momento da publicação deste trabalho, ainda não possui vacina efetiva, nem medicamento, além de causar controvérsias quanto à divulgação dos dados de infectados e mortos no Brasil, o que acarreta desentendimentos com a Organização Mundial da Saúde - OMS e bloqueios internacionais. da educação básica e superior tem se tornado urgente, uma vez que os cortes de 
verbas, as reformas educacionais e as correntes anti-científicas têm ameaçado a autonomia e a ação crítica dos professores, que podem ter as QSC como elemento fundamental para controverter as aulas de ciências e levar os alunos a refletirem e agirem diante dos problemas sociocientíficos.

Assim, diversos pesquisadores da área têm proposto a inserção dos aspectos CTS e das questões sociocientíficas na formação de professores, no intuito de que suas práticas sejam guiadas por fundamentos teóricos propícios à formação de agentes sociais críticos. Tal premissa não acarreta em que a relação entre teoria e prática seja linear ou simples, mas é importante discutir a formação de professores de ciências no seu âmbito mais abrangente e crítico. Estas pesquisas também apontam para o potencial do jogo de papéis e das questões sociocientíficas para a efetivação dos pressupostos do movimento CTS nos currículos e nas aulas de ciências, cujos argumentos serão explorados nas discussões teóricas deste trabalho.

Entretanto, ainda são necessários trabalhos que divulguem, compreendam e problematizem práticas efetivas com as QSC nas aulas de ciências da educação básica e na formação de professores, principalmente com a perda precoce do Professor Wildson Santos em 2016, cujas contribuições para o campo das relações CTS e educação em ciências foram inestimáveis. É com este intuito que propomos estas discussões e esperamos que as interpretações sobre a experiência com o júri simulado nas aulas de metodologia de ensino de física na formação de professores sejam potenciais para o avanço do conhecimento da área e como motivação para a reestruturação dos cursos de formação.

\section{A FORMAÇÃO DE PROFESSORES NO CONTEXTO DAS QUESTÕES SOCIOCIENTÍFICAS}

Para autores que descrevem trabalhos nas correntes da educação CTS, como Aikenhead (s/d), Cross e Price (2002) e Solomon (1993), a educação baseada em questões sociocientíficas requer dos estudantes competência no entendimento de múltiplas perspectivas, reflexão crítica e posicionamento. Os objetivos da educação, nesta perspectiva, buscam refletir na cidadania e na responsabilidade social, com abordagens críticas e cognitivas. Entretanto, poucos trabalhos têm mostrado a inserção de ações em sala de aula com a abordagem das questões sociocientíficas na formação de professores.

Nesta linha de pesquisa, Alves, Carvalho e Mion (2009) interagem a investigação temática de Paulo Freire, a educação CTSA e a formação inicial de professores de física. Para eles, a inserção de temas controversos nos currículos, como aquecimento global e a questão energética, pode ser o início de um processo de conscientização. Para nós, a efetivação destes temas na educação básica ou superior podem ocorrer por meio das QSC.

Embora Santos (2011) apresente controvérsias em torno das definições atuais utilizadas no campo da educação CTS e do declínio do uso da sigla no mundo, ainda nos posicionamos em função das questões sociocientíficas, de acordo com Pedretti e Nazir (2011) com a corrente dos temas que levam em conta a justiça socioambiental, como descrito no quadro a seguir: 
Quadro 1 - Correntes em CTSA (PEDRETTI; NAZIR, 2011, p.607-8)

\begin{tabular}{|c|c|c|c|c|}
\hline Corrente & Foco & $\begin{array}{l}\text { Visão de } \\
\text { ensino de } \\
\text { ciências }\end{array}$ & $\begin{array}{l}\text { Abordagens } \\
\text { dominantes }\end{array}$ & $\begin{array}{c}\text { Exemplos de } \\
\text { estratégias }\end{array}$ \\
\hline $\begin{array}{l}\text { Aplicação/ } \\
\text { projeto }\end{array}$ & $\begin{array}{l}\text { Resolução de } \\
\text { problemas por meio } \\
\text { de novos projetos } \\
\text { tecnológicos ou } \\
\text { modificando a } \\
\text { tecnologia existente } \\
\text { com ênfase nas } \\
\text { investigações e } \\
\text { habilidades }\end{array}$ & $\begin{array}{l}\text { Utilitarista, } \\
\text { prática, } \\
\text { resolução de } \\
\text { problemas, } \\
\text { transmissão } \\
\text { do } \\
\text { conhecimento } \\
\text { disciplinar e } \\
\text { habilidades } \\
\text { técnicas }\end{array}$ & $\begin{array}{l}\text { Cognitiva, } \\
\text { experimental, } \\
\text { pragmática e } \\
\text { criativa }\end{array}$ & $\begin{array}{l}\text { Aprendizagem } \\
\text { baseada em } \\
\text { problemas e } \\
\text { construção de } \\
\text { artefatos }\end{array}$ \\
\hline Histórica & $\begin{array}{l}\text { Entendimento das } \\
\text { inter-relações } \\
\text { histórico-culturais } \\
\text { das ideias da ciência } \\
\text { e do trabalho dos } \\
\text { cientistas }\end{array}$ & $\begin{array}{c}\text { Realização } \\
\text { cultural e } \\
\text { intelectual e } \\
\text { valor } \\
\text { intrínseco } \\
\text { (interessante, } \\
\text { excitante e } \\
\text { necessário) }\end{array}$ & $\begin{array}{l}\text { Criativa, } \\
\text { reflexiva e } \\
\text { afetiva }\end{array}$ & $\begin{array}{c}\text { Estudo de casos } \\
\text { históricos, } \\
\text { jogos de papéis } \\
\text { e } \\
\text { dramatizações }\end{array}$ \\
\hline $\begin{array}{l}\text { Raciocínio } \\
\text { lógico }\end{array}$ & $\begin{array}{l}\text { Entendimento das } \\
\text { questões, tomada de } \\
\text { decisão sobre } \\
\text { questões } \\
\text { sociocientíficas por } \\
\text { meio de evidências } \\
\text { empíricas }\end{array}$ & $\begin{array}{l}\text { Cidadania, } \\
\text { responsabilida } \\
\text { de cívica, } \\
\text { tomada de } \\
\text { decisão } \\
\text { (pessoal e } \\
\text { social) e } \\
\text { barganha de } \\
\text { ideias. }\end{array}$ & $\begin{array}{l}\text { Reflexiva e } \\
\text { cognitiva }\end{array}$ & $\begin{array}{c}\text { Uso de } \\
\text { questões } \\
\text { sociocientíficas, } \\
\text { análises de } \\
\text { risco/benefício, } \\
\text { análise das } \\
\text { partes } \\
\text { interessadas, } \\
\text { uso de modelos } \\
\text { de } \\
\text { argumentação, } \\
\text { modelos de } \\
\text { tomada de } \\
\text { decisões e } \\
\text { debates }\end{array}$ \\
\hline $\begin{array}{l}\text { Centrada } \\
\text { em valores }\end{array}$ & $\begin{array}{l}\text { Entendimento das } \\
\text { questões, tomada de } \\
\text { decisão sobre as } \\
\text { questões } \\
\text { sociocientíficas por } \\
\text { meio de } \\
\text { considerações éticas } \\
\text { e raciocínio moral }\end{array}$ & $\begin{array}{l}\text { Cidadania, } \\
\text { responsabilida } \\
\text { de cívica, } \\
\text { tomada de } \\
\text { decisão } \\
\text { (pessoal e } \\
\text { social) e } \\
\text { barganha de } \\
\text { ideias }\end{array}$ & $\begin{array}{l}\text { Afetiva, moral, } \\
\text { lógica e crítica }\end{array}$ & $\begin{array}{c}\text { Estudos de } \\
\text { caso, análise de } \\
\text { questões } \\
\text { sociocientíficas, } \\
\text { uso de } \\
\text { estruturas } \\
\text { filosóficas de } \\
\text { moral, } \\
\text { esclarecimento } \\
\text { de valores e } \\
\text { decisões morais }\end{array}$ \\
\hline
\end{tabular}




\begin{tabular}{|c|c|c|c|c|}
\hline $\begin{array}{c}\text { Sociocultur } \\
\text { al }\end{array}$ & $\begin{array}{l}\text { Entendimento da } \\
\text { ciência e da } \\
\text { tecnologia } \\
\text { coexistentes em um } \\
\text { amplo contexto } \\
\text { sociocultural }\end{array}$ & $\begin{array}{l}\text { Realização } \\
\text { cultural e } \\
\text { intelectual e } \\
\text { barganha de } \\
\text { ideias }\end{array}$ & $\begin{array}{l}\text { Holística, } \\
\text { reflexiva, } \\
\text { experimental } \\
\text { e afetiva }\end{array}$ & $\begin{array}{l}\text { Estudos de } \\
\text { caso, uso de } \\
\text { questões } \\
\text { sociocientíficas, } \\
\text { inclusão de } \\
\text { sistemas de } \\
\text { conhecimentos } \\
\text { alternativos, } \\
\text { tradicional e } \\
\text { espiritual, } \\
\text { narrativas e } \\
\text { currículo } \\
\text { integrado }\end{array}$ \\
\hline $\begin{array}{l}\text { Justiça } \\
\text { socioambi } \\
\text { ental }\end{array}$ & $\begin{array}{c}\text { Crítica, resolução de } \\
\text { problemas sociais e } \\
\text { ecológicos por meio } \\
\text { de ações ou ativismo } \\
\text { humanos }\end{array}$ & $\begin{array}{l}\text { Cidadania, } \\
\text { responsabilida } \\
\text { de social, } \\
\text { resolução de } \\
\text { problemas, } \\
\text { transformação } \\
\text { e } \\
\text { emancipação }\end{array}$ & $\begin{array}{l}\text { Criativa, } \\
\text { afetiva, } \\
\text { reflexiva, } \\
\text { crítica, } \\
\text { experimental } \\
\text { e local }\end{array}$ & $\begin{array}{c}\text { Uso de } \\
\text { questões } \\
\text { sociocientíficas, } \\
\text { estudos de } \\
\text { caso, projetos } \\
\text { comunicativos, } \\
\text { debates, } \\
\text { desenvolviment } \\
\text { o de planos de } \\
\text { ação e uso de } \\
\text { contextos locais } \\
\text { e globais }\end{array}$ \\
\hline $\begin{array}{c}\text { Aplicação/ } \\
\text { projeto }\end{array}$ & $\begin{array}{c}\text { Resolução de } \\
\text { problemas por meio } \\
\text { de novos projetos } \\
\text { tecnológicos ou } \\
\text { modificando a } \\
\text { tecnologia existente } \\
\text { com ênfase nas } \\
\text { investigações e } \\
\text { habilidades }\end{array}$ & $\begin{array}{c}\text { Utilitarista, } \\
\text { prática, } \\
\text { resolução de } \\
\text { problemas, } \\
\text { transmissão } \\
\text { do } \\
\text { conhecimento } \\
\text { disciplinar e } \\
\text { habilidades } \\
\text { técnicas }\end{array}$ & $\begin{array}{l}\text { Cognitiva, } \\
\text { experimental, } \\
\text { pragmática e } \\
\text { criativa }\end{array}$ & $\begin{array}{l}\text { Aprendizagem } \\
\text { baseada em } \\
\text { problemas e } \\
\text { construção de } \\
\text { artefatos }\end{array}$ \\
\hline
\end{tabular}

Fonte: Autor (2017).

Tendo em vista o quadro anterior, as questões sociocientíficas podem ser trabalhadas de diversas maneiras, segundo as visões de ensino de ciências, da própria epistemologia da ciência e de acordo com a metodologia de ensino escolhida. Assim, a defesa pela educação científica, de acordo com as questões sociocientíficas, é baseada na necessidade da formação política e na compreensão de ciência pela sociedade para a sua participação efetiva nos temas que influenciam sua vida.

Assim, o estudo realizado por Piolli e Costa (2008) refere-se a qual o mínimo de informação necessária para subsidiar conhecimentos sobre a QSC para que as pessoas possam participar? Os autores afirmam que o conhecimento especializado, quando propositor de desigualdade de participação entre experts e leigos, passa a ser visto como uma ameaça política, cujo poder de decisão acaba nas mãos destes poucos especialistas. Neste contexto, o Estado, com sua suposta neutralidade, acaba por conferir aos especialistas a responsabilidade por tais decisões sendo que, a população em geral é a que sente diretamente os efeitos 
destas escolhas. Assim, o objetivo da formação de professores poderia ser o de questionar, refletir e agir em função da atenção aos currículos, conteúdos e conhecimentos necessários à compreensão e à participação pública em C\&T.

Deconto, Cavalcanti e Ortermann (2016), ao discutirem a literatura do campo da formação de professores sob a perspectiva CTS, apontam para a inexpressividade de práticas que formem professores para o trabalho efetivo com este enfoque em sala de aula. De acordo com esta ideia, os autores propõem a discussão sobre as concepções de futuros professores de física sobre o movimento CTS, a partir da qual foi possível verificar os equívocos que podem ser expressos nas concepções de ciência e tecnologia destes professores, ao relacioná-las às questões sociais. Neste sentido, os autores evidenciaram a necessidade de investimentos na formação de professores na perspectiva do movimento CTS.

Esta formação corresponde à abrangência de atividades dos professores, como conhecer, compreender e poder influenciar nas políticas e propostas para a educação pública, mais que suas tarefas cotidianas e burocráticas, como a reprodução de currículos e conteúdos descontextualizados e inexpressivos. Porém, estas ações não podem ser compreendidas de maneira desligada da prática docente, pois a escola reproduz os padrões sociais, além da própria construção do conhecimento, ambos os aspectos devem ser entendidos como propícios de participação social, portanto, como inerentes aos conhecimentos e ao trabalho do professor.

Entretanto, Barbosa e Catani (2003, p.11) reconhecem os problemas em formar profissionais críticos "no interior do Estado, quase sempre para servi-lo, e com a simultânea esperança de que seja possível que estes proponham a inovação e sejam capazes de afrontar o mesmo Estado na defesa de ideais socialmente defensáveis". O mesmo problema é levantado por Pimenta (2002), que infere sobre como o Estado liberal desconhece a importância do professor na educação da sociedade da informação. Para a autora, a perpetuação da educação, com a propagação indiscriminada das informações tem a ver com o professor comprometido em transformar tais informações em conhecimento, revelando valores na constituição da sociedade. Neste caso, os profissionais críticos apenas reconhecem seu pensamento como crítico, mas como a crítica e o saber podem vir a interferir na superação da reprodução social?

Assim, propomos que a profissionalização docente deva ser imersa em esferas de debate que incluam, primordialmente, os agentes mais diretos. Neste caso, os agentes envolvidos são os próprios professores, que são "capazes de avaliar em plena consciência, o trabalho de seus pares" (KEMMIS, 1993, p.6). Estes agentes vivenciam e compartilham problemas, possibilidades, experiências, entre outros elementos que compõem o mundo da escola.

Nesta perspectiva, a própria noção de autonomia se refere ao professor como participante de deliberações no campo educacional, assim como na prática cotidiana de sala de aula e de interação com os pares. Como afirma Contreras (2002), "a autonomia do professor em sala de aula, como qualidade deliberativa da relação educativa, se constrói na dialética entre as convicções pedagógicas e as possibilidades de realizá-las, de transformá-las nos eixos reais do transcurso e da relação de ensino" (p.198). E, por isso mesmo, "tanto a autonomia profissional como pessoal não se desenvolvem nem se realizam, nem são definidas pela capacidade de isolamento, pela capacidade de 'se arranjar sozinho', nem pela 
capacidade de evitar influências ou as relações" (idem, p.199). Ao contrário, a autonomia, vista sob a perspectiva crítica, tem na intersubjetividade o meio para a formação social e para a emancipação.

Por isso, nossa posição começa a ser direcionada para um modelo de atuação política e autônoma dos professores, em que

Tal pretensão política se traduz no fomento de formas de democracia participativa, nas quais os setores envolvidos podem intervir sem mediações na definição coletiva das finalidades, na conjugação dos interesses particulares com os gerais e na decisão compartilhada em condições de efetiva igualdade política (CONTRERAS, 2002, p.220).

É o mesmo que afirmar que devem ser garantidos espaços, condições e autonomia para que os professores possam refletir e reformular suas concepções sobre ensino, bem como expor estas concepções diante um público interessado, que as debata e reformulem uma posição diante à esfera pública educacional. Esta situação se distancia substancialmente das propostas curriculares, que colocam os professores como executores. No primeiro caso, a ação é comunicativa, no segundo a intenção é comunicada aos educadores.

Portanto, as expressões dos referenciais de formação de professores apresentados constituem teoria suficientemente apropriada à concepção de educação CTS e questões sociocientíficas que propomos neste trabalho, aquela que visa a formação de professores e estudantes para a compreensão e a participação das e nas questões controversas que envolvem ciência e tecnologia. Tais relações apontam para que os professores possam decidir sobre temas, conteúdos e currículos a serem levados às salas de aulas, que sejam adequados às questões atuais e urgentes das sociedades em nível local, regional, nacional ou global, como os exemplos de QSC que já expusemos. Assim, foi sobre patamares desta natureza que a disciplina de metodologia e prática de ensino de física foi desenvolvida junto aos estudantes de licenciatura em Física desta IFES, disciplina na qual tivemos o momento do júri simulado como fechamento e momento de constituição de dados deste trabalho, neste sentido, a seguir apresentamos uma breve discussão sobre a importância deste tipo de atividade para a situação formativa que constituímos e como foi delineada a metodologia de constituição e interpretação dos dados.

\section{DELINEAMENTO DA PESQUISA: O JÚRI SIMULADO E A SITUAÇÃO FORMATIVA}

Iniciamos este trabalho questionando sobre quais os aspectos formativos da experiência com júri simulado nas aulas de metodologia de ensino na formação inicial de professores de física? Para desenvolver as discussões em torno deste problema, propomos uma atividade com o júri simulado em uma disciplina de metodologia e prática de ensino de física, em um curso de licenciatura em física de uma Universidade Federal no interior do estado de São Paulo. Assim como temos discutido, as QSC, de acordo com Martinez (2014, p. 85), são questões que, em geral, são divulgadas em grandes meios de comunicação, podem abarcar valores morais e éticos, podem ser de cunho global ou local, estão relacionadas com interesses pessoais e de grupos sociais e têm embasamento em conhecimento científico. 
Assim, Vieira et.al (2014, p.2), ao realizarem estudo similar com os júris e a formação de professores afirmam que:

\begin{abstract}
We acknowledge the simulated jury as a particular type of role-play activity (McSharry \& Jones, 2000). In simulated jury activities, future science teachers (hereing-after referred also as 'pre-service teachers') can assume different roles, such as defender, opponent and judge of the posed arguments (for a theoretical account of these argumentative roles, see Plantin, 2005). Also, they can interchange their roles, exerting all the role possibilities and, of course, can experience roles that they do not necessarily assume as yours in one given situation (Vieira, Melo \& Bernardo, 2014). Finally, in these juries pre-service teachers are expected to have active roles in knowledge production, which may have positive impact on their learning (VIEIRA, 2014, p. 2).
\end{abstract}

Os mesmos autores acreditam que o exercício argumentativo nos júris simulados podem contribuir para o desenvolvimento de um processo de descentralização relacionado à autonomia dos futuros professores. Além disso, desenvolvem competências argumentativas necessárias à prática docente, além da capacidade de análise de temas controversos que envolvem C\&T e a confiança para a atuação na sociedade.

Como metodologia de ensino, o júri simulado pode ser conduzido pelo professor no papel de mediador e organizador das discussões, enquanto os alunos podem atuar em grupos de interessados, como jogo de papéis. Normalmente, em QSC, há grupos de interesses econômicos, ambientais, sociais, religiosos, científico-tecnológicos, civis, governamentais entre tantas outras possibilidades que variam de acordo com o tema a ser discutido. Assim, torna-se interessante que os participantes possam transitar entre as diferentes perspectivas, justamente para desenvolver a argumentação, o reconhecimento da importância da diversidade de posicionamentos em temas controversos e a insuficiência e a predominância de determinada posição em detrimento de outras, por exemplo, quando o argumento científico se sobrepõe aos argumentos éticos e morais.

Além da perspectiva apresentada, o júri simulado na formação inicial de professores pode possibilitar que os licenciandos reconheçam as potencialidades e as limitações deste tipo de atividade para as aulas de ciência. Assim, os dados analisados neste trabalho foram constituídos a partir de um júri simulado desenvolvido em uma aula de metodologia e prática de ensino de física, num curso de licenciatura em física de uma IFES, no primeiro semestre de 2016. Esta atividade contou com a presença de oito licenciandos (LC, GH, AD, DL, RF, AT, HG e CT), além da professora da turma. $O$ júri compunha um dos requisitos para o trabalho sobre metodologias de ensino no campo com as questões sociocientíficas. Neste sentido, a produção destes dados teve alguns elementos que foram potenciais, no sentido de valorização e investimento na prática, uma vez que o júri também fazia parte da avaliação da disciplina, como requisito para aprovação, um dos fatores que contribuíram para que os licenciandos investissem nas pesquisas de campo e de literatura sobre os temas discutidos.

O texto problematizador do júri foi elaborado pela professora da turma e idealizava o aumento de produção de energia elétrica para a cidade fictícia de "Tranquilina do Sul", baseada em uma cidade do interior do estado de São Paulo, cujas possibilidades de geração de energia são diversas, como hidrelétricas, termoelétricas, usinas eólicas, fotovoltaicas, etc. O texto apresentava uma 
controvérsia sociocientífica, na medida em que o prefeito "Sr.Progresso", sociedade civil, comerciantes, industriais e ambientalistas discordavam sobre a melhor fonte de energia a ser utilizada pela cidade, na ocasião da implantação de novas indústrias na cidade, com argumentos representativos de seus grupos sociais, aqueles que estão ligados às QSC, como argumentos éticos, morais, econômicos, ambientais, científicos, econômicos etc. A atividade foi desenvolvida a partir de uma exposição inicial de cada grupo, seguida por momentos de perguntas, respostas, réplica e tréplica, com o tempo delimitado pela professora. Ao final, esperávamos encontrar um consenso sobre a ação a ser tomada sobre o problema fictício, o que foi entregue em forma de um relatório único elaborado por todos os grupos.

Neste processo, a pesquisa educacional foi do tipo qualitativa, no sentido em que "lida com pessoas e seus contextos de vida, bem como questões filosóficas relacionadas à natureza do conhecimento e da verdade (...), dos valores (...) e do ser (...) que embasam os critérios e as atividades humanas" (SOMEKH et.al, 2015, p.27). Além disso, a pesquisa também foi participante, que dentre outras características, teve todos os envolvidos na constituição dos dados também como pesquisadores, ou seja, a professora e os alunos que participaram do júri também são pesquisadores em ensino de ciências e autores deste trabalho.

Para fins de sistematização dos dados, lançamos mão da análise de conteúdo que, de modo geral, Moraes (1999) define o processo de categorização, como "um procedimento de agrupar dados considerando a parte comum existente entre eles. Classifica-se por semelhança ou analogia, segundo critérios previamente estabelecidos ou definidos no processo" ( $\mathrm{s} / \mathrm{p})$. As categorias devem ser válidas, pertinentes ou adequadas, o que caracteriza a sua validade. O autor definirá categorias previamente constituídas ou constituídas a partir dos dados. Entretanto, na pesquisa que desenvolvemos, elegemos eixos temáticos que emergiram de ambos os processos e são mais abrangentes que as categorias, ou seja, a escolha dos temas destes eixos temáticos foi decorrente tanto da leitura preliminar das transcrições, quando das teorias que guiaram nossas discussões, e seus títulos buscam explicitar as ideias principais dos agrupamentos de falas.

\section{ANÁLISES E INTERPRETAÇÕES DOS DADOS}

A partir das discussões nas quais propomos o júri simulado como contexto da constituição dos dados, e lançando mão da análise de conteúdo, pudemos apresentar eixos temáticos para explicitar os elementos potenciais e as limitações da prática realizada. Neste sentido, optamos por apresentar as falas que sustentam tais eixos nos quadros a seguir, cujas discussões procuram relacionar os aspectos importantes das falas com as discussões teóricas já desenvolvidas. Para alguns eixos temáticos, ainda foi possível identificar subeixos, cujos assuntos se relacionam aos temas mais amplos, mas apresentam discussões cujas especificidades julgamos importantes de serem evidenciadas.

O primeiro eixo de análise se refere ao início da atividade, quando foi necessária a introdução de aspectos normativos para o trabalho que seria realizado, o que denominamos como ação normativa, em referência à Jürgen Habermas. De acordo com o autor, estas ações reguladas por normas têm o caráter de manifestações providas de sentido, inteligíveis, vinculadas às pretensões de 
validez e suscetíveis de crítica, não fazem referência aos fatos, mas às normas e vivências. São aquelas cujos membros do grupo orientam suas ações para normas comuns que expressarão um acordo, as propostas apenas são julgadas segundo critérios de verdade e eficácia e se interessa pelos aspectos de conteúdo pertinentes à linguagem. Este tipo de ação dificilmente é observado na escola, pois necessita de organizações que possibilitem que os agentes deliberem as normas que regem suas ações (HABERMAS, 1994).

Quadro 2 - Ação normativa

\begin{tabular}{|c|c|c|}
\hline $\begin{array}{c}\text { Eixo } \\
\text { Temático }\end{array}$ & Subeixo & Trechos \\
\hline $\begin{array}{c}\text { Ação } \\
\text { normativa }\end{array}$ & & $\begin{array}{l}\text { Professora: Como base nisso, iremos fazer o júri simulado. } \\
\text { Eu havia colocado aqui que a discussão seria orientada de } \\
\text { modo que cada grupo tem em torno de } 3 \text { minutos para } \\
\text { expor seus argumentos, seguido de perguntas livres dos } \\
\text { representantes sociais, com } 1 \text { min de resposta, 1min de } \\
\text { tréplica, a gente seguiria essa ordem. O que eu proponho, } \\
\text { tem uma ordem aleatória aqui para mim. Tem o grupo da } \\
\text { energia eólica, o grupo da energia fotoelétrica, } \\
\text { termoelétrica e hidrelétrica. Eu pensei em fazer essa } \\
\text { exposição inicial nessa ordem, e depois a gente levanta o } \\
\text { dedo para fazer as perguntas e respostas, sem } \\
\text { necessariamente, ficar contando o tempo. } \\
\text { Professora: Vamos seguir a ordem dos grupos, um faz } \\
\text { uma pergunta a qualquer grupo, ele responde, quando a } \\
\text { gente terminar a rodada vai pro grupo } 2 \text {, pode ser? Grupo } \\
\quad 1 \text { escolhe o grupo e faz a pergunta } \\
\text { Professora: Gente, proponho mais uma rodada com } \\
\text { perguntas direcionadas e depois um debate geral. Pode } \\
\text { ser? Então voltando pro G1... }\end{array}$ \\
\hline
\end{tabular}

Fonte: Autor (2017).

Em termos destas ações normativas, parece que deve haver este papel para a organização dos momentos, uma vez que ainda não há uma cultura de comunicação de modo geral, ao contrário, o que é possível encontrar nos debates sociais são embates de opiniões pouco fundamentadas e que podem acarretar desentendimentos. Na atividade que realizamos, este papel ainda ficou relegado ao professor, que contava com o assentimento dos alunos, mas houve um silenciamento das ações normativas por parte deles. Justamente porque compreendemos a necessidade deste tipo de ação para as discussões sociocientíficas, é que podemos afirmar como ainda é urgente formar pessoas para as discussões democráticas, cuja participação é fundamental para que existam consensos verdadeiros. à soberania popular, uma vez que não existem direitos humanos onde quem deveria possuí-los não os reconheça por não os ter definido, ou seja, não dá pra ser titular de direitos quando não se é também, autor desses direitos. Porque o ato de participação popular de forma soberana é o que legitima o processo democrático discursivo, os direitos subjuntivos que contemplam 
todos e os direitos que são referidos a uma parcela, em particular, devem ser requeridos de forma clara, transparente e visando a equidade (LEITE, 2005, p. 200-1). É relevante perceber que, para Habermas, o importante é permitir que os envolvidos construam ou elaborem suas próprias normas pois isso legitima o processo (RIBEIRO, 2012, p. 85-86).

A citação descreve de maneira efetiva uma das conclusões sobre a atividade, a de que o trabalho com as questões sociocientíficas podem contribui para o desenvolvimento da formação para as ações normativas, que respaldam ações comunicativas e que são fundamentais para os processos de compreensão e participação públicas em ciência e tecnologia. Assim, formar pessoas para que elaborem suas próprias normas e orientem a formulação de leis gerais passa a ser também objetivos desta educação crítica com as QSC e da formação inicial de professores.

Por fim, esta ação normativa também passa por ponderar e compreender que o tempo das discussões nem sempre são suficientes, neste sentido, foi deliberado pelo grupo que houvesse mais tempo para a elaboração de um relatório com as ponderações dos argumentos expostos e com uma proposta de ação para o problema discutido no júri.

Em continuidade às interpretações, no quadro abaixo selecionamos o eixo temático referente aos argumentos econômicos relacionados à questão sociocientífica de "Tranquilina", como subeixos pudemos reconhecer ainda que estes argumentos, muitas vezes, se referiam às ideias de eficiência e de relações entre custos e benefícios.

Quadro 3 - Argumento econômico

\begin{tabular}{|c|c|c|}
\hline $\begin{array}{c}\text { Eixo } \\
\text { Temático }\end{array}$ & Subeixo & Trechos \\
\hline $\begin{array}{l}\text { Argumento } \\
\text { econômico }\end{array}$ & & $\begin{array}{l}\text { DL: As vantagens para a comunidade, como a empresa } \\
\text { está inserida em uma comunidade, a gente tem uma } \\
\text { preocupação em quais as vantagens que ela traz para a } \\
\text { comunidade. Os parques eólicos podem ser utilizados, } \\
\text { não só como parque eólico, dá para utilizar como fonte } \\
\text { de agricultura, como passagem de gado, por exemplo. } \\
\text { Então, uma área de um parque eólico deve ser grande, } \\
\text { mas por outro lado, pode ser utilizado para outras } \\
\text { coisas, sem ser só a geração de energia. Ela gera uma } \\
\text { criação de emprego grande, demanda de trabalhadores } \\
\text { na área e tudo mais. Normalmente, o investimento que } \\
\text { é feito, é em zonas mais desfavorecidas, são em zonas } \\
\text { mais isoladas, e para os donos da terra ou os donos dos } \\
\text { lugares onde tem de ficar, ela acaba trazendo também } \\
\text { benefícios financeiros } \\
\text { Para quem irá investir, tem as vantagens para os } \\
\text { investidores. Ela não necessita de abastecimento de } \\
\text { combustível, a manutenção não é tão grande, é escassa } \\
\text { desse tipo de gerador, e a rentabilidade é grande, } \\
\text { porque o que é gasto com manutenção e tudo mais, }\end{array}$ \\
\hline
\end{tabular}


mais ou menos em 6 meses ele já tem o retorno desse investimento.

AT: As centrais da energia fotoelétrica têm manutenção mínima, por que? Uma vez instalada, a manutenção é pouco porque não há motivo de ir ou pagar alguém para verificar todos os dias a central. Outro ponto importante, relacionada ao baixo custo da manutenção, é que cada placa solar dura em média 30 anos. Você faz um investimento inicial, que é relativamente alto, mas você não precisa ficar sempre renovando isso porque é vantajoso, nesse ponto, porque durante 30 anos é válido.

CT: Certo, o que a gente também tem que pensar e já foi mencionado, é que nós temos uma cidade extremamente pequena, 15 mil habitantes, e nós temos que estar conscientes de que não é qualquer coisa, de qualquer valor, que pode ser implantado ali. No caso a termoelétrica tem essa vantagem de ser extremamente barata, recursos próximos, linhas de transmissão próximas da cidade e dos centros urbanos, então temos essas vantagens. No caso, dentre essas alternativas, a termoelétrica seria assim a mais barata na sua implantação.

DL: Além disso, a empresa trabalha com projetos sociais sobre o uso inteligente da energia. Esse uso inteligente,

Eficiência é usar com eficiência, procurando produtos eficientes, e usar com moderação, usar conforme a necessidade, evitando desperdício.

AT: A relação custo-benefício, o custo é bastante alto, mas vem caindo. A potência, a capacidade de gerar energia vem aumentando. No Brasil, a energia solar, como o Brasil é um país tropical, ela pode ser produzida durante o ano todo, diferente de alguns outros países

que, por exemplo, países longe dos trópicos, a produção de energia solar não é eficiente durante o ano todo, e por isso, tem de existir outros tipos de usinas para produzir energia. Não emite poluentes, ao contrário de outras fontes produtoras de energia, como

Relação custo $X$ benefícios as termoelétricas, elas não produzem poluentes, e no geral, os especialistas afirmam que é uma energia com grande potencial em desenvolvimento, que como o passar do tempo vai se tornar uma coisa muito importante.

As desvantagens do nosso tipo de energia: é caro, a gente tem essa consciência. $\mathrm{O}$ armazenamento da energia nas placas solares acaba se tornando um pouco ineficiente, mas com o avanço da tecnologia, como era antes e como é hoje, já melhorou bastante. Temos consciência também, todo mundo sabe através de estudos, que a instalação dessa usina tem de ser um 
pouco afastada da cidade ou de algum local que tem muitas pessoas, porque ela acaba gerando morte de aves, por causa do calor. Como ela fica em um lugar, e ela gera uma luz, acaba atraindo aves, e essas aves ao chegar perto morrem queimadas. $E$ as pessoas tem que morar afastadas por causa do calor, que é muito alto.

LC: Na verdade, o grande ponto da energia solar é o custo inicial para instalação. Só que esse custo inicial, ele acaba sendo compensado pelo custo da manutenção que é mínima. Você não tem a necessidade de reparar os geradores solares constantemente, então você não vai ter gasto com isso. O custo da implantação, ele realmente é alto, mas ele acaba produzindo uma fonte de energia que acaba compensando, então acaba valendo a pena.

Quanto à população, esses painéis solares podem ser construídos de maneiro a suprir os custos das indústrias. Então, com as indústrias vindo para Tranquilina do Sul, isso vai gerar novos empregos, vai movimentar a economia da cidade, o que vai gerar mais renda pra cidade.

RF: Uma das atividades de Tranquilina é a questão da agricultura, sendo uma das bases que motivam o trabalho da população, da pequena população de Tranquilina. E instalando ou viabilizando qualquer manejo no Rio Sossego, como é que a gente vai, como é que vocês vão adaptar o trabalho de modo a não interferir nos sistemas de irrigação e no uso continuo, porque vocês já destacaram a pesca, mas e o sistema de irrigação que tá movendo a agricultura? LC: Bom, quanto a questão do valor, realmente, ele é alto, mas, além do fato da potência estar aumentando, o custo para implementação está diminuindo. Outro ponto que compensa na questão do custo é que ela pode ser instalada em locais onde não existem pontos de transmissão. Então, a gente vai acabar tendo que colocar em uma região um pouco afastada da população devido ao calor e ela pode ser implementada em locais onde não há linha de transmissão, o que acaba diminuindo o custo, embora seja alto para implantação, o custo que você transmitir essa energia não é alto. $O$ fornecimento de energia solar acaba sendo constante, por mais que tenha oscilações, uma vez que funciona por pressão de radiação, esse fornecimento acaba sendo mais ou menos constante e acaba compensando. caso de problemas com energia eólica e outro sobre 
A exposição dos argumentos econômicos foi importante, uma vez que os futuros professores assumiram os papeis, de tal modo que compreendem a existência de argumentos diversos em uma discussão sociocientífica. Ou seja, mesmo tendo consciência das implicações e da necessidade de se levar em conta outros tantos aspectos, como os éticos, os sociais e os ambientais, eles puderam exercitar a habilidade de ponderação de tais argumentos. De modo geral, esta situação contribuiu para que os professores aprendam a lidar com situações controversas em sala de aula, de modo a estimular a exposição dos argumentos, ao invés de impor determinado ponto de vista ou finalizar precocemente uma questão, de modo a impedir os dissensos. Estes elementos concordam com as discussões apresentadas por Vieira et.al (2014) para a formação de professores de ciências por meio dos pressupostos do movimento CTS, uma vez que temas urgentes e problemáticos que envolvem ciência e tecnologia não podem mais estar ausentes das pautas da educação em ciências.

A seguir, podemos acompanhar como os licenciandos continuaram a exposição de outros argumentos relacionados à QSC de Tranquilina, com o levantamento de aspectos ambientais, sociais e científicos deste tema. Neste sentido, os quadros abaixo expressam estes argumentos como eixos temáticos e subeixos, de modo a evidenciar argumentos mais específicos e que fazem relações diversas às dos eixos principais. 
Quadro 4-Argumento ambiental

\begin{tabular}{|c|c|c|}
\hline $\begin{array}{c}\text { Eixo } \\
\text { Temático }\end{array}$ & Subeixo & Trechos \\
\hline $\begin{array}{c}\text { Argumento } \\
\text { ambiental }\end{array}$ & & $\begin{array}{l}\text { GH: Exatamente, a construção desse reservatório que } \\
\text { causa a maior quantidade dos impactos dentro da } \\
\text { construção da hidrelétrica, porque gera desmatamento, } \\
\text { gera a maior alteração dentro da fauna e da flora da região } \\
\text { onde vai ser instalado. } \\
\text { AD: Então, a nossa proposta é construir essa usina de fio } \\
\text { d'água. Nesse ponto, a gente considera que não irá causar } \\
\text { impacto muito grande na atividade pesqueira, que era um } \\
\text { dos grandes clamores da população. Inclusive para o } \\
\text { turismo, porque você não vai precisar desabitar a } \\
\text { população, você só precisar construir uma barragem para } \\
\text { usar a velocidade e a energia potencial e cinética do rio. } \\
\text { AD: Outra questão importante, é que o planejamento do } \\
\text { prefeito é expandir, ou seja, a gente ainda tem um escape } \\
\text { com a presença da termoelétrica. Porque a gente parte do } \\
\text { pressuposto que ela vai ser um complemento para a usina. } \\
\text { GH: Mas isso em caso de emergência, ou seja, em caso de } \\
\text { seca, em casos normais a hidrelétrica é suficiente para } \\
\text { sanar a demanda de energia das empresas que querem se } \\
\text { instalar na cidade. } \\
\text { AD: Ah, pro grupo a energia solar pode ser considerada } \\
\text { limpa e tão vantajosa assim se grande parte dos } \\
\text { componentes utilizados são fabricados na China, que tem } \\
\text { uma energia baseada basicamente em carbono, ou seja, } \\
\text { pra gerar energia limpa você usa energia suja. }\end{array}$ \\
\hline & $\begin{array}{c}\text { Custos } \\
\text { Ambientais } \\
\mathrm{X} \\
\text { Benefícios }\end{array}$ & $\begin{array}{l}\text { GH: Agora, é claro que esse tipo de construção traz } \\
\text { algumas desvantagens com relação ao reservatório. Essa } \\
\text { desvantagem vem justamente nesse caso, em caso de } \\
\text { seca, em caso de o rio não estar com um nível tão alto, a } \\
\text { produção vai diminuir, porque eu não tenho um } \\
\text { reservatório para escoar a água, e aumentar a minha } \\
\text { produção. Mas, a gente parte do pressuposto de que o rio } \\
\text { é caudaloso, ou seja, já apresenta a característica assim. } \\
\text { Mas, uma alternativa que nós temos é, que nós sabemos } \\
\text { da existência de uma hidrelétrica rio acima. Uma outra } \\
\text { hidrelétrica rio acima. Possivelmente, como a maioria é, } \\
\text { ela tem um reservatório. Então, o que que acontece, no } \\
\text { caso desse rio apresentar baixa, eles vão abrir esse } \\
\text { reservatório, e a hidrelétrica de Tranquilina vai acabar } \\
\text { recebendo o escoamento dessa água também, por tabela. } \\
\text { Então, pode ser que isso não seja um problema, por conta } \\
\text { da existência desse hidrelétrica rio acima. } \\
\text { LC: Quanto ao ponto levantado sobre energia solar não } \\
\text { produzir a noite, o motivo pelo qual estamos aqui para } \\
\text { decidir qual forma de energia instalar é para abastecer a }\end{array}$ \\
\hline
\end{tabular}


demanda industrial, e essa funciona em horário comercial, e nesse horário possui luz solar, quando a indústria não estiver funcionando a demanda cai, então e necessidade de energia alta não será 24 horas por dia, com base nisso, eu gostaria de citar alguns pontos que foram destacados pelo New York Times em 2010 a respeito da energia eólica.

Essa matéria foi publicada no dia 07/10/2010, e fala especificamente acerca do barulho gerado pelas turbinas eólicas, então para situar todos, foram vários casos nos Estados Unidos, e alguns pontos relevantes. Além dos EUA, conflitos semelhantes aconteceram no Canadá, GrãBretanha, inclusive em outros países que geram e usam da energia eólica como fonte predominante. $O$ grande foco da matéria é a reclamação do barulho.

Fonte: Autor (2017).

Diante da exposição dos argumentos ambientais, as falas expressam cenários realísticos das questões sociocientíficas atuais, justamente aqueles cujos danos ambientais são inevitáveis, e nestes casos, as exposições vão em direção às relações entre impactos ambientais e os benefícios de cada tipo de fonte de energia. Ressaltamos estas controvérsias, uma vez que muitas discussões de QSC podem caminhar em direção ao conceito de sustentabilidade. Neste sentido, o professor deve estar atento a não reforçar conceitos naturalizados, que são aqueles utilizados ao mesmo tempo e deliberadamente pela indústria, pelos ambientalistas, por grupo econômicos e políticos.

\begin{abstract}
Uma vez que todos defendem o desenvolvimento sustentável - ricos e pobres, exploradores e explorados, incluídos e excluídos -, algo deve estar errado nisso. Esse termo polissêmico, ao ser usado em muitos contextos, parece ter contribuído mais para manter a "lógica vigente" do que para realmente questioná-la e alterá-la. (ANGOTTI; AUTH, 1995, p.17)
\end{abstract}

Assim, as questões sociocientíficas também são potenciais para controverter os termos disseminados na sociedade, mas que, ao serem abordados em sala de aula, podem levar as pessoas a questionarem os interesses e problemas relacionados a eles. Neste sentido, ao desenvolver tais problematizações com os futuros professores, eles passam a conhecer as possibilidades formativas destas discussões, mesmo que a relação entre o que se aprende nos cursos de formação inicial e a prática em sala de aula não seja linear, pudemos reconhecer nas falas dos licenciandos habilidades argumentativas importantes para a docência. Ainda de acordo com estas ideias, o quadro a seguir apresenta falas nas quais são apresentados os argumentos da ciência, nas quais também podemos localizar este exercício em controverter argumentos naturalizados ou tidos como certezas pela sociedade.

Quadro 5 - Argumento da ciência

Trechos

\begin{tabular}{|c|c|c|}
$\begin{array}{c}\text { Eixo } \\
\text { Temático }\end{array}$ & Subeixo & Trechos \\
\hline $\begin{array}{c}\text { Argumento } \\
\text { da ciência }\end{array}$ & & $\begin{array}{c}\text { AD: Como o GH falou, a gente tem um rio do lado da cidade de } \\
\text { Tranquilina, e a gente pode considerar, assim como o Sol, a }\end{array}$ \\
\hline
\end{tabular}


energia que não contribui para o aquecimento global.

Ela basicamente, foi dito no texto que a população estava com medo, pois havia meses atrás, aparecido uma substância de mau cheiro que causou a mortandade de diversos peixes, e a população está receosa de que isso pode ser proveniente da usina hidrelétrica. Mas, se a gente ver como é feita a construção de uma usina hidrelétrica, ela é feita basicamente de reservatório, barragem, um duto que faz girar uma turbina e a velocidade da água, energia cinética e energia potencial, é transformada em energia elétrica. Portanto, em relação a essa questão da substância com mau cheiro, a gente pode garantir que não é proveniente da usina hidrelétrica. Deve ter sido qualquer outro fator que não está relacionado com a nossa usina, porque ela não usa produtos químicos. Ela só transforma energia potencial e cinética em elétrica.

Além disso, se a gente considerar o rio Sossego Cristalino como caudaloso, como o GH falou, ele já utilizado por uma usina hidrelétrica, um tipo de usina hidrelétrica que vem sendo utilizada no país, desde a década de 90 , é chamada de fio d'água. Ela não cria um reservatório muito grande, ela basicamente cria uma barragem no rio para usar só a velocidade da água, ou seja, recentemente o Greenpeace fez um relatório ambiental argumentando contra a construção de Belo Monte. Ele argumentava justamente nesse ponto, que se cria um reservatório muito grande, que mata uma grande área de floresta, e isso faz com que a energia não seja mais limpa, porque você vai ter o solo e todas as plantas ali em decomposição, mas se você olhar no desenho aqui, depois eu passo, essa área é mínima, ou seja, o impacto ambiental desse tipo de construção é mínimo. Ou seja, aquilo que o Greenpeace chamava de ponto negativo para a usina hidrelétrica, com esse tipo de construção, de fio d'água, não acontece.

GH: Fora que vocês já comentaram o problema dos pássaros, então vocês agregam o problema dos pássaros mais o problema da poluição envolvida na fabricação dos componentes dos painéis solares.

AT: Bom, os componentes utilizados na fabricação dos painéis solares a gente sabe que a maioria é zinco. Então, a gente consegue ter um controle dessa produção em níveis aceitáveis de extração desses minérios. Em relação à mortalidade das aves, a gente não tem uma solução bem definida com relação a isso, é uma coisa meio que complicada.

AD: Agora, considerando a nossa região, que é a região central do Estado, a gente pegou uma usina próxima da cidade de Tranquilina, também na região central do estado. Só que ela usa o rio Tietê, que é a cidade Uracéia. Uracéia tem uma hidrelétrica e ela fica abaixo da cidade de Bariri. Essa usina é do 

gente considerar que a gente precisa de $365 \mathrm{MW} / \mathrm{h}$ por mês, considerando 143 de uma usina que seria muito parecida que a gente pode construir na cidade, em um mês a gente teria de forma bruta $512,2 \mathrm{GW} / \mathrm{h}$ pra cidade, ou seja, supri toda a necessidade energética da cidade e ainda oferece mais, pra

casos de expansão do mercado industrial da cidade.

RF: Na verdade o planejamento da Wind Energy (empresa fictícia criada pelo grupo de defesa da energia eólica) já prevê um estudo prévio da cidade e nas ultimas médias anuais, os dias que menos teve índice de ventos, nós tivemos ventos de 3 $\mathrm{m} / \mathrm{s}$ que já é suficiente pra movimentar as pás. Obviamente, nós não estamos isentas a uma eventualidade natural que é uma escassez total do vento, mas os equipamentos já têm um sensor que é o anemômetro. Ela já vai fazendo as medições prévias, então nós temos um sistema que consegue prever baixas de ventos, e nós antes da energia ser distribuída, ela tem um sistema de armazenamento de energia em baterias, então se for por algumas horas ou para poucos dias, nós ainda conseguimos manter uma liberação de energia porque foi preparada.

DL: A gente tem um estudo aqui que fala da velocidade média anual do vento, a cinquenta metros de altura, que é a altura média das torres, e por esse estudo ele fala que na região onde vai ser instalada a usina, ela consegue mesmo nas baixas, no período de baixo vento, ele consegue suprir a necessidade que as empresas no caso vão ter.

CT: Certo. Estive pesquisando um pouco acerca da energia eólica, e daquilo que eu encontrei de informação é que haveria uma condição necessária para que essa energia fosse aproveitada realmente com eficiência. No caso, essa condição

se dá que é pelo menos a cinquenta metros de altura a velocidade do vento seria de $7 \mathrm{~m} / \mathrm{s}$. No entanto, somente $13 \%$ da superfície terrestre é capaz de obedecer a esta condição. E eu busquei também um mapa que trazia pra mim que mais ou menos na região central do estado de São Paulo, a velocidade do vento no campo aberto seria de mais ou menos entre $4,5 \%$

a $6 \%$. Então eu gostaria de questionar a viabilidade de se implantar o parque eólico aí nessa região.

RF: Sim. Retomando seu dado, sua pesquisa diz respeito a torres de até $50 \mathrm{~m}$. Hoje a agência de minas e energia prevê que no Brasil já existe regulamento pra instalação de torres um pouco superiores, que é de $80 \mathrm{~m}$, condicionando uma vez que nós temos o potencial de $143,5 \mathrm{GW} / \mathrm{s}$ em todo Brasil com torres a 80 m. Esta é a nova regulação que vem desde 2005 . Então, o que acontece: como o aumento desses $30 \mathrm{~m}$ a gente teve uma crescente de pelo menos $50 \%$ da nossa produção, embora os teus dados estejam completamente corretos na questão da velocidade dos ventos e na produção e energia, a 
nossa empresa está mais especializada em torres de $80 \mathrm{~m}$, já

pautando a produção e explorando melhor o potencial de energia eólica no brasil.

Fonte: Autor (2017).

A maioria dos alunos foi surpreendida pela possibilidade do uso da usina fio d'água, por isso, aparecem argumentos que levam em consideração este tipo de barragem. De fato, a apresentação desta nova possibilidade energética causou a necessidade de inserções de aspectos científicos e estatísticos por parte dos argumentantes. Entretanto, podemos observar como as estatísticas aparecem sempre acompanhadas de ponderações do tipo social ou ambiental, ao contrário do que normalmente pode-se esperar deste tipo de discussão, cujos argumentos científicos costumam ter força maior que outras qualidades de ponderações, de modo a acarretar em decisões precoces pautadas apenas no saber dos especialistas. Nestes casos, as relações CTS acabam subsumidas apenas ao saber técnico, distanciando a sociedade civil das decisões das QSC.

Ao contrário destas situações, os professores podem conduzir os alunos às discussões sobre natureza da ciência que possibilitam discutir os limites da ciência, quando os assuntos são controvertidos em termos sociais e ambientais. Tais ideias são corroboradas por Sadler e Zeidler (2004, p.387), ao afirmarem que:

Findings indicate that interpretation and evaluation of conflicting evidence in a socioscientific context is influenced by a variety of factors related to NOS (nature of science) such as data interpretation and social interactions including individuals' own articulation of personal beliefs and scientific knowledge (SADLER; ZEIDLER, 2004, p.387).

Neste trabalho, os autores buscaram, justamente, observar como os estudantes lidam com as informações em torno das QSC, como interpretam os dados, as relações culturais e como lidam com os argumentos contrários, de modo que puderam notar a importância de se inserir aspectos da natureza da ciência (NOS para a sigla em inglês), para que o conhecimento especializado não fosse a visão predominante nestas discussões. Assim, no trabalho que realizamos, também pudemos perceber como os futuros professores lidam com a informação científica de modo a ponderar os aspectos sociais e ambientais.

Ao final das discussões, os futuros professores puderam compreender a complexidade da questão, de modo que, ponderar os argumentos apresentados constituía tarefa mais complexa do que imaginaram inicialmente. Em fato, era importante que eles reconhecessem os problemas relacionados aos posicionamentos e decisões precoces, cujas ações podem acarretar malefícios à sociedade envolvida. Assim, os licenciandos puderam discutir o tema de modo a não mais representar determinado papel, mas sim como futuros professores a abordar questões sociocientíficas em sala de aula, expressando assim, as suas concepções reconstruídas a partir das exposições de argumentos. No quadro a seguir, apresentamos discussões gerais que levaram em consideração todos os aspectos apresentados durante o júri simulado. 
Quadro 6 - Ponderação dos argumentos

\begin{tabular}{|c|c|c|}
\hline $\begin{array}{c}\text { Eixo } \\
\text { Temático }\end{array}$ & Subeixo & Trechos \\
\hline $\begin{array}{l}\text { Ponderação } \\
\text { dos } \\
\text { argumentos }\end{array}$ & & 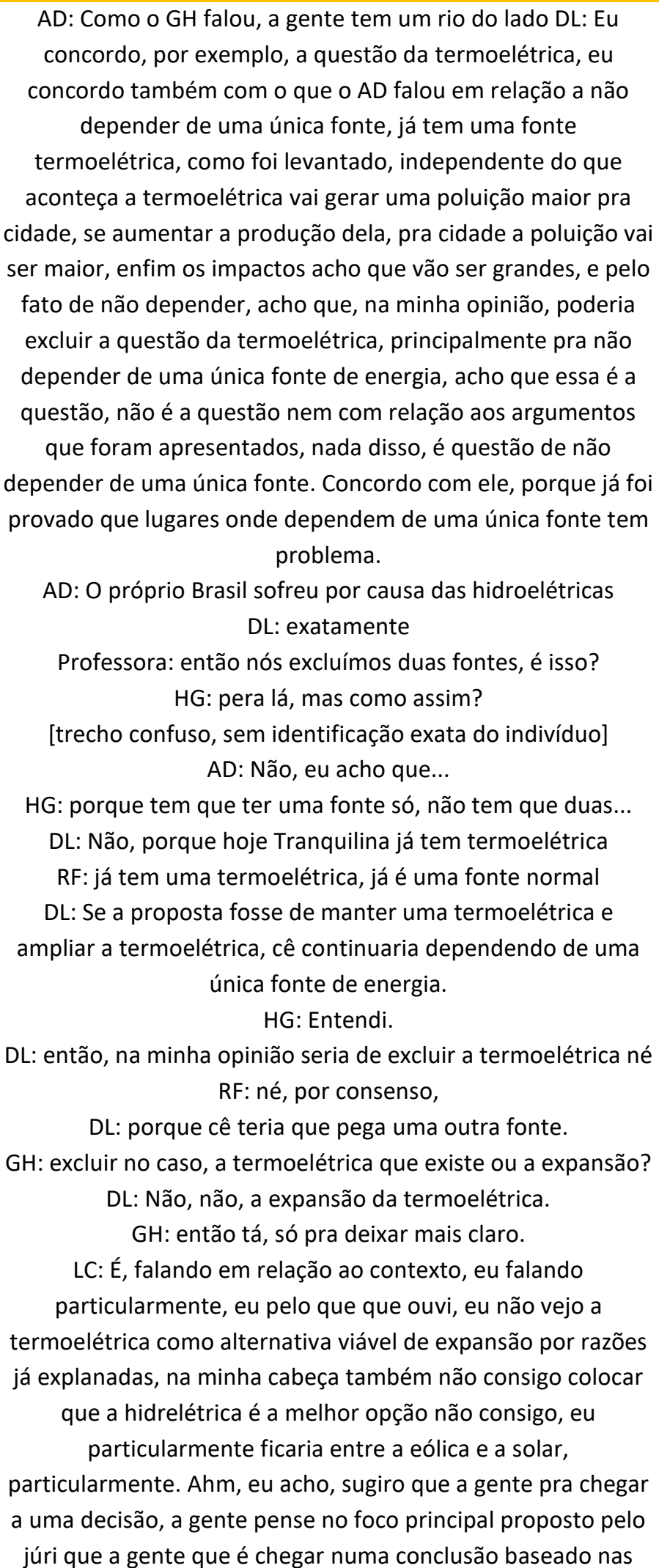 \\
\hline
\end{tabular}


necessidades que englobam a indústria que vai se instalar e os impactos na população. (ruídos). Então, é, qual que é a maneira mais eficiente de ajudar a indústria e ao mesmo

tempo não prejudicar a população. E, ao meu ver, as alternativas mais viáveis que conseguem balancear as duas coisas é a eólica e a solar

GH: Eu não vejo assim porque eu acho que o custo da solar vai ser uma coisa muito fora pro habitante da cidade que está acostumado com uma energia que vem de uma termoelétrica pequena

AD: que já é cara.

AT: que não é barato

$$
\mathrm{GH}: \mathrm{ahm} \text { ? }
$$

AT: que não é barato

GH: que não é barata, mas, aí você agregar a essa termoelétrica, uma solar que ainda mais cara, eu acho que pros habitantes de uma cidade rural, eu acho que é uma coisa que vai pesar absurdo [inaudível]

DL: fica menos eficiente

$A D$ : por mais que fique barato ao longo do tempo $\mathrm{GH}$ : por mais que fique barato ao longo do tempo, vai ser um impacto pro habitante na hora, naquele momento que chega aquela... aquela...

AD: a conta

$\mathrm{GH}$ : a conta pra ele mesmo vai ser um impacto absurdo. Eu imagino se fosse outro lugar, protestos em cima do valor da conta, porque seria um impacto muito grande, eu imagino.

LC: Vocês fizeram alguma previsão em relação ao custo pra implantação da hidrelétrica?

GH: Pra implantação?

LC: é o custo pra construir e falar "ah, tá funcionando"..

AT: é barato?

LC: Alguém fez?

AD: não, não, não fiz.

DL: não, mas, tá dentro..

Professora: o CT fez.

DL: CT você fez?

CT: Certo, eu na verdade fiz com relação a termoelétrica foi onde também eu tive alguns, algumas informações acerca da hidrelétrica. Na pesquisa que eu fiz, as últimas termoelétricas implantadas no Brasil, elas tinham um custo em reais médio de 2147 reais por kwatts pra implantação. Também encontrei neste mesmo trabalho, a informação de que a energia hidrelétrica GH: a Hidrelétrica.

CT: a hidrelétrica seria por volta de 2600, 2700. AD: a implantação 
CT: exatamente e a eólica seria por volta de 4200, 4300 reais por kwatts, e também encontrei uma informação bastante interessante se opondo àquilo que o DL vem falando. A manutenção ela é nula. Eu não penso assim.

DL: não. Não falei que é nula, falei que é baixa.

CT: Certo. Daquilo que encontrei nessa mesmo, nesse mesmo trabalho, dizia que a manutenção da energia eólica, ela aumentava em decorrência do tempo e apresentava alguns gráficos. Não me aprofundei nisso, mas, ela aumentava em decorrência do tempo.

$$
\text { (ruídos) }
$$

HG: vai remendando

Professora: oi?

HG: vai remendando

GH: bom, então dá pra ver o que o custo da hidrelétrica por exemplo nem é tão alto assim de implantação

AD: seria bem próximo da ampliação, da ampliação da termoelétrica.

Professora: Diante disso?

AD: Eu ainda acho, na minha concepção (risos) fica a hidrelétrica e termoelétrica.

(falas confusas não audíveis no fundo)

CT: Não, não. Mas, também acho que uma coisa que há necessidade de se considerar é que nos leilões de energia passados, a gente construiu hidrelétricas e compramos usinas termoelétricas porém a diesel, a carvão, e essas sim são muito mais caras, mais baratas na implantação que a biomassa, mas, elas são muito mais caras quando se usa para a geração de energia elétrica. No entanto, elas são utilizadas apenas pra fim de complementação. Eu, particularmente penso que, há necessidade de diversificar as fontes de energia. Construir uma hidrelétrica como os projetos $\mathrm{da}$, da, do $A D$ e do $\mathrm{GH}$, seria

bastante interessante, mas, também concordo com a expansão da termoelétrica, por que? Os cursos de água, eles podem reduzir, o fluxo pode reduzir e pode ser necessário uma complementação dessa energia, já que a gente tem a cana de açúcar, que ela se mantém fixa vamos dizer assim, todo o ano a gente consegue produzir sem problema nenhum. AD: Mas, se falta água na hidrelétrica pode ser que falte água pra irrigar a cana, e no caso a hidrelétrica tem, conta com um volume da hidrelétrica acima.

CT: Certo, Certo.

GH: Eu, eu particularmente não concordo que numa sociedade que já tem um enfoque rural, você aumentar uma matriz energética que depende do trabalho agrícola, eu acho que é você de certo modo, vamos dizer acontecer igual, fica igual o caso da bijuteria de Limeira, você acostuma a população com uma coisa que, com uma situação que pode ser que não seja 

população num aumento da produção da cana e não é bom pra uma cidade que já tem essa característica rural. AT: é, uma coisa que eu quero falar também é que na hora que eu fui lá, acabou passando, que nem eles, ele levantou a questão que se um dia venha a faltar água, etc, que seja um.. um caso extremo. Mas, que nem: a seca que a gente viu no último ano foi bem assustador, todo mundo ficou super assustado.

$A D$ : acho que foi a maior dos últimos anos AT: isso, e conforme a gente vê estudos, não sei se tá qual, a qual empresa que estuda enfim, a gente veem observando nos jornais que a falta de água daqui pra frente vai ser cada vez mais constante, então, a gente não pode prever que não.. não

vá faltar água pra.. não vai chegar nem a, a hidrelétrica depender do volume morto, por exemplo. Entendeu, então a gente tem que fazer previsões pra uma fonte de energia que seja realmente eficiente porque daqui pra frente vai estreitar a coisa, então, a gente tem que tá preparado pra tudo, porque a gente lida com tecnologia. Então, a gente tem que ter uma tecnologia que não dependa de muitas outras coisas.

Entendeu? De outros fatores. [trecho inaudível]

HG: aquecimento global, mais quente, mais energia, sol [ruídos]

AD: calor ou com solar?

GH: eu acho que é assim, a cidade atualmente a termoelétrica por si só ela já abastece a necessidade da população, o abastecimento a mais, ele vai vim pro abastecimento da indústria. Então acredito assim, num (inaudível) de emergência extrema, vamos dizer assim, a população não vai ser afetada, mesmo que a hidrelétrica vamos dizer pare e a termoelétrica continue, a população inicial não será afetada. Vai ser afetada a indústria a mais. Claro que isso vai gerar impacto? isso vai gerar impacto, mas, a gente tá pensando num caso extremo.

RF: isso pra qualquer uma das empresas, como pra qualquer uma de nossas empresas [ruídos]

GH: a gente tá pensando numa condição extrema por isso que eu acredito que a construção da hidrelétrica e a permanência da termoelétrica é uma solução plausível pra necessidade da cidade hoje.

AT: Mas, a gente tem que levar em consideração também que você trazendo indústrias novas pra cidade vai aumentar a população ai isso é, aumenta

$A D$ : oh, o cálculo que a gente fez

AT: aumenta os extremos. 
$A D$ : o, tem uma sobra de [inaudível - tosse]

AT: Funcionando, né?

AD: Funcionando.

AT: Na falta, a gente não pode prever né.

AD: na falta...

AT: assim, na escassez de água, igual a gente

AD: é um caso extremo

AT: ah, mas é extremo mas não é impossível, a gente sabe que vai acontecer

$A D$ : a mesma coisa é a gente considerar que tem falhas geológicas que podem fazer um vulcão entrar em erupção e tapar a entrada de sol na atmosfera.

[ruídos]

RF: Nossa, mas nós estamos falando do Estado de São Paulo

$A D$ : mas tem casos que podem acontecer e ter um impacto global.

HG: Mas, qual que é a chance de acontecer isso e a chance de acontecer uma seca por exemplo

AD: então, eu não fiz a pesquisa pra saber se é muito mais

HG: então, eu já vi muita seca na minha vida, mas, nunca vi um vulcão...

[muitos risos]

AD: não, mas, vocês 'tão' contando com uma coisa que pode acontecer e que seja grave, eu também 'to'.

HG: não, eu tô contando 19 anos da minha vida, eu já vi várias secas mas nunca vi um vulcão no Brasil.

LC: é, a seca é uma realidade presente (inaudível)

$A D$ : mas, não tão grave quanto o, ele tá levantando de secar o rio

AT: é só pensar em Mariana, gente.

Professora: parece que a gente não tá nem perto de chegar a uma conclusão

AT: temos Mariana que dá pra ver que uma seca pode Professora: eu fico, eu achei que eu tava bem posicionada, mas, ai veio outro argumento, agora não to mais [risos]

LC: não, eu ainda acho que [inaudível]

Professora: não, eu vou fazer considerações pra tentar chegar numa conclusão e logo

AT: eu acho que você vai ter que intervir

Professora: não, intervir agora, mas, eu vou fazer ponderações muito generalizadas porque assim eu acho que, de acordo com os argumentos, eu não tenho dúvida de que particularmente, particularmente não, ponderando todos os argumentos, eu sempre fui bastante contrária a cana em virtude de que ela é socialmente desprezível, o balanço energético da cana a gente não leva em consideração todo o processo dela, entretanto, a biomassa é um resíduo da cana, 

descarte dela geraria a produção, esse argumento que não foi

de fato ai vastamente explorado, então, você não tá diretamente relacionado a esta questão. Então, você pensa, é... eu um bom descarte, dou um bom fim pra aquela coisa. [inaudível]. Mas, mesmo assim né, na minha concepção, é tampar o sol com a peneira, eu ainda tô dando um jeitinho de usar aquilo que não queria que existisse mais. Então, sou fortemente inclinada a não querer né, a, embora muitas vezes eu fico "ai vamos ficar com a cana vai", fico pensando que não, quando vem pra esse argumento a gente não... tem que se apegar alguns parâmetros e eu descarto bastante fortemente a energia...

$A D:$ Mas tem que levar em conta que se não descartar o bagaço da cana eu vou fazer o que com ele depois? Professora: $\mathrm{E}$, tem uma questão com relação a hidrelétrica que me deixou muito temerosa, que é a questão mesmo da seca: que dá pra ficar contando com a água e tal, e ainda assim, você pegar há uma produção muito conservadora de energia é contramão do mundo, né muito embora eu fiquei surpresa com a apresentação da represa do fio d'agua né, isso de fato não tá ligado a.. [inaudível]

RF: Eu não conhecia

AT: Nem eu, conheci pesquisando.

Professora: ligado ao tradicional, eu vi, estava esperando a construção de uma barragem

RF: eu acho que, esse é o consenso né

Professora: então, o fio d'agua, de fato, chama a atenção mas também fico com medo de ir na contramão de uma tendência global né que são as energias solar e eólica. $E$, mas, o custo né assusta, uma cidade desse porte a gente ainda fica bastante preso né, no Brasil de um modo geral a gente fica preso às tecnologias né, mas é progressista né. A tecnologia, ligada ao avanço, a eólica ainda menos dependente de clima do que a solar, mas, a solar você pode fazer grandes, não é recente, mas tem grandes estudos inclusive de uma amiga de vocês, a

Thaisa, que demonstra

HG: que você vai virando pro movimento do sol. Professora: que 50\% de aproveitamento a mais de energia eólica se você acompanhar o movimento do sol. [inaudível]

Professora: então há possibilidade de aumentar a eficiência energética dessa empresa do sol, e foram aspectos aí que vocês poderiam ter trazido e que eu tô trazendo aqui talvez até pra controverter mais ai essa questão. Então, diante destes aspectos eu vou aqui pensando na minha questão. Mas, gostaria de ver se o grupo consegue delimitar mais. $\mathrm{GH}$ : você trouxe mais dificuldade pra chegar na deliberação 
AT: achei que você ia apresentar uma solução, uma

HG: eu achei que a gente te confundiu, a gente tá te confundindo

[trecho inaudível]

$\mathrm{GH}$ : Mas, portanto

[inaudível - risos]

AT: eu tava entre a hidrelétrica, mas, realmente a seca é uma questão muito efetiva.

RF: o que me preocupou nessa hidrelétrica, nesse modelo ai que do, do.

$\mathrm{GH}$ : do fio d'agua

RF: do fio d'agua é que eu não sei se vocês viram pelo esquema ilustrativo ai, você tem um desvio de uma parcela do rio, tá vendo que ele não passa pelo...

AD: Aqui? [mostra na imagem]

RF: Isso, exato. É isso, é exatamente esse ponto, esse desvio que gera aquela pergunta que eu fiz do quanto você vai perder

a mais ali porque você fazer um desviozinho de um né AD: então, não sei eu no texto quando eu olhei eu falei: mas pra que que serve isso? Será que pra passar com barco depois RF: é exatamente pra isso.

$A D$ : eu não consegui obter a informação se isso acontece em todas as barragens

RF: porque no caso da barragem, o que é que a gente tem? A gente tem os pontos de acesso, tipo a gente tem aqui ó (aponta para um desenho).

DL: eclusas.

RF: As eclusas, é esse o nome que você faz o nivelamento da água pra permitir a passagem e esse desvio que você, que você apresenta nessa ilustração é justamente pra você ter o desvio pra pequenas embarcações e tal pra não ter a

$A D$ : Pode ser que seja isso, eu não tenho certeza, depois eu fui pegar uma imagem da represa de Bariri lá, eu não lembro o nome da cidade. [trecho pouco audível] E lá eu não vi esse tipo de estrutura, pode ser que isso seja apenas ilustrativo. Professora: eu gostaria de colocar outra pretensão, como juíza, como juíza mor [inaudível] não é essa questão que eu falei, a gente pode inovar ué, nós não estamos presos a esta situação não é, e eu acabei colocando outros elementos pra essa discussão que controverteu mais, eu senti isso, pelo menos dos elementos que eu tinha trazido e que controverteram e controvertem ainda mais a questão. É, então, principalmente com essa relação do atraso científico e tecnológico que o Brasil tem e também com relação a esses aspectos, ainda custos altos com ciências e tecnologia, esse temor de ficar a mercê de chuva, e de duas fontes de energia muito conservadoras ai no Brasil, proponho: daqui duas semanas que vocês apresentem um relatório final com uma conclusão de todos vocês.

Fonte: Autor (2017). 
Nesta ponderação dos argumentos, os alunos se propuseram a compreender todos os aspectos levantados durante as discussões, com o intuito de concluir encaminhamentos para a QSC abordada, a partir da ponderação das informações apresentadas. Sadler e Zeidler (2004) também questionaram como os estudantes interpretam e avaliam informações conflitantes em QSC, de modo que puderam perceber que "While this assumption may hold true in some Science classroom scenarios, the approach fails to explicitly emphasize a critical area of socioscientific interactions: moral and ethical implications. Many of the questions faced by modern society require more than the cognition that science plays a central role in their solutions" (p.389-390). Entretanto, nas discussões dos alunos na disciplina, houve um silenciamento dos aspectos éticos e morais, de modo que nesta conclusão, pudemos reconhecer a predominância dos aspectos éticos e científicos.

Assim, nos questionamos o porquê desta dificuldade em discutir assuntos éticos e morais que persiste na sala de aula. Elementos sociais que poderiam ser ligados ao tema poderiam dizer respeito ao trabalho escravo que ainda existe nas plantações de cana-de-açúcar, bem como a retirada de moradores ribeirinhos, a submersão completa de cidades para a construção de barragens, o superfaturamento de obras para a construção de barragens, entre outras discussões que foram ignoradas pelos futuros professores. Temos por hipótese, que abordar controvérsias éticas nas aulas de ciências ainda pode ser um problema para os professores, uma vez que estas controvérsias levam em consideração posicionamentos pessoais e políticos, bem como crenças e aspectos morais relativos que podem acarretar conflitos entre os alunos. Nestes casos, os professores persistem no tratamento dos aspectos científicos e técnicos, uma vez que ainda apresentam um ideário de neutralidade e cientificidade que dificilmente colocarão estes conhecimentos em xeque durante as aulas. Portanto, ressaltamos a necessidade de que trabalhos desta natureza explorem mais as questões éticas e morais das QSC e que estes conhecimentos façam parte da formação dos professores de ciências.

\section{CONCLUSÕES}

Desenvolvemos este trabalho no sentido de discutir as implicações de práticas com questões sociocientíficas e júris simulados para a formação de professores de ciências, nas concepções da crítica e da autonomia. Inicialmente, nos pautamos na necessidade de trabalhos na área que apresentem pesquisas realizadas no âmbito destas experiências, em função de pesquisas que apontam para as potencialidades da intersecção das questões sociocientíficas e a formação de professores. Nesse sentido, no processo que desenvolvemos, pudemos levantar junto aos futuros professores, como atividades desta natureza podem ser potencialmente formativas para a sua carreira docente, uma vez que as teorias apresentadas versam sobre a autonomia e a crítica como elementos fundamentais para que os professores superem a condição reprodutivista de sua prática.

Por outro lado, foi possível levantar limitações da experiência, uma vez que alguns elementos importantes foram silenciados pelos licenciandos, como a participação pública e os aspectos éticos e morais. De modo que não houve qualquer indicativo sobre como a população poderia estar envolvida nas decisões ou como tais decisões poderiam afetar a vida das comunidades locais. Contudo, os alunos levaram em consideração a qualidade de vida da população, como o fato 
da usina hidrelétrica de fio d'água não prejudicar os pescadores e a instalação da usina solar em locais afastados da cidade, por exemplo. Dessa forma, pudemos observar como a questão social esteve presente nas discussões, embora não estivesse ligada às questões éticas e morais. Portanto, explicitamos como ainda é limitada a inserção de aspectos axiológicos na sala de aula e a necessidade cada vez mais urgente de que estes temas sejam incluídos nas pautas educacionais.

Esta constatação está ligada ao modelo linear de desenvolvimento, já vastamente criticado pelas pesquisas do campo CTS, cujo entendimento leva à crença de que o desenvolvimento científico e tecnológico poderia acarretar desenvolvimentos econômicos e sociais, sem afetar aspectos éticos e ecológicos da vida humana.

Assim, concluímos que o júri simulado permite aos futuros professores uma ferramenta para a abordagem de QSC de maneira complexa, de modo a estimular a habilidade argumentativa e a possibilidade de formulação de temas e currículos próprios e localizados para a educação em ciências. E, embora durante a atividade, tenha ocorrido a ausência das ponderações sobre a sua potencialidade como metodologia do ensino de física por meio das QSC, a escrita deste trabalho nos possibilitou realizar importantes sistematizações e reflexões coletivas sobre estes aspectos, o que certamente se dirige ao empoderamento do professor como aquele que pesquisa a prática e constitui conhecimento educacional.

Como aspecto mais importante desta pesquisa, pudemos concluir como o problema da inserção das QSC na sala de aula passa por um complexo de condicionantes que não somente aqueles relegados à formação de professores, pois não basta a formação inicial abranger estes aspectos para garantir que estas questões estarão nas salas de aula. Quando o professor se insere na escola e se depara com os currículos, com as condições de sala de aula, relações interpessoais entre outros elementos, não basta ter conhecimento das QSC para que realize práticas voltadas à estas controvérsias. Sadler e Zeidler (2009, p. 404) chegaram à conclusão semelhante ao desenvolver experiências com as questões sociocientíficas, de modo que corroboram com a ideia de que não basta inserir as QSC nos currículos ou apenas formar os professores "Teachers need training in order to effectively integrate NOS and socioscientific issues in their classrooms. Programs to help deliver NOS instruction have been successfully developed and implemented (for an example, see Clough and Olson 2001), and we argue for the continuation of these efforts". Ou seja, estes resultados de pesquisa apontam para a complexidade do trabalho com as questões sociocientíficas, que devem se voltar para todos os âmbitos da educação, mas principalmente por políticas e programas de formação de professores em níveis inicial e continuada.

Neste complexo pensamento, certamente não é possível realizar hierarquizações, de modo que a implementação das QSC não deveriam vir "de cima para baixo", em formato de currículo, mas justamente a formação de professores poderia ser aquela voltada para formar professores capazes de construir currículos localizados, com QSC de acordo com os contextos e necessidades da população em nível local, regional, nacional ou global. De modo que a experiência que realizamos mostrou a importância de se discutir temas presentes nas vidas das pessoas, cujas discussões do tipo júri simulado possibilitaram que os participantes transitassem entre o conhecimento cotidiano, para informações relevantes e confiáveis para a argumentação. 
Portanto, a agenda do ensino de ciências deve ter em pauta o compromisso com a transformação, ao contrário do que é apontado na literatura em geral, que baseia os objetivos da educação CTS para a tomada de decisões somente no nível da ação pessoal e pontual. Por isso, além da utopia, como agentes comprometidos com a educação e a formação, nos cabe a vigília permanente e o cuidado profícuo com os objetivos, propostas e transformações da educação em ciências no contexto das questões sociocientíficas. 


\title{
CONSIDERATIONS ON WORKING WITH THE JURY SIMULATED ON A SOCIO-SCIENTIFIC ISSUE WITH FUTURE PHYSICS TEACHERS
}

\begin{abstract}
In this research, we sought to develop understandings about the work carried out during a simulated jury on a socio-scientific question (QSC) in the methodology of teaching physics in a Federal Institution of Higher Education (IFES), since there is still a gap in the Which refers to the studies that were prepared to interpret as practices of this nature may be potential for the training and performance of future teachers. Socio-scientific questions were linked to the implementation of a new source of electric power in the fictional city of Tranquilina do Sul, whose aspects of science, technology, society, environment and ethics made the issue controversial. The simulated jury was based on the role play between the actors responsible for the different proposed energy sources and representatives of society, as well as the mediation of the class teacher who led the discussion to choose one of these sources. In the end, we were able to understand the importance of the work that covered scientific, technological, environmental and social concepts that characterize the theme as socio-scientific. From the analyzes and interpretations, we could also propose discussions and inferences about the potential of this practice for the training of teachers and for teaching science.
\end{abstract}

KEYWORDS: STS. Energy. Role play. Science teaching. Physics teaching. Teacher training. 


\section{REFERÊNCIAS}

AIKENHEAD, Glen S. Science communication with the public: a cross-cultural event. In: BRYANT, Chris; GORE, Mike; STOCKLMAYER, Sue (Eds.) Science Communication in Theory and Practice. The Netherlands: Kluwer Academic Publishers (forth coming).

ALVES, João A. P.; CARVALHO, Washington L. P.; MION, Rejane A. Investigação temática na formação de professores de física e no ensino de física. IN: NARDI, Roberto (Org.) Ensino de Ciências e Matemática, I: temas sobre a formação de professores. São Paulo: Cultura Acadêmica, 2009, p.11-26.

ANGOTTI, José A.P. Conceitos unificadores e ensino de física. Revista brasileira de ensino de física, 15 (1-4), p.181-189, 1995.

BARBOSA, Raquel L.L.; CATANI, Denice B. Formar educadores: desafios para todos os tempos. In: BARBOSA, Raquel L.L.(org.) Formação de educadores: desafios e perspectivas. São Paulo: Editora da UNESP, 2003, p.11-x.

CROSS, Roger.; PRICE, Ronald. Teaching Controversial Science for Social Responsibility: The case of Food Production. In: ROTH, Wolff-Michael. e DÉSAUTELS, Jacques. Science Education as/for sociopolitical action. New York: Peter Lang Publishing, p.99-123, 2002.

CONTRERAS, José. A autonomia de professores. Tradução: Sandra Trabucco Valenzuela. São Paulo: Cortez, 2002.

HABERMAS, J. Racionalidade e comunicação. Tradução: Paulo Rodrigues. Lisboa: edições 70, 1996.

KEMMIS, Stephen. La formación del profesor y la creación y extensión de comunidades críticas de profesores. Investigación en la escuela, n.19, 1993, p.1538.

MARTINEZ P, Leonardo F. Cuestiones sociocientíficas en la formación de profesores de ciencias: aportes y desafíos. Rev. Fac. Cienc. Tecnol., Bogotá, n. 36, p. 77-94, July 2014. Disponível em: $<$ http://www.scielo.org.co/scielo.php?script=sci arttext\&pid=S012138142014000200006\&lng=en\&nrm=iso>. Acesso em 16 Aug. 2016.

MARTINEZ PEREZ, L. F.; CARVALHO, W. L. P. de. Contribuições e dificuldades da 
from <http://www.scielo.br/scielo.php?script=sci_arttext\&pid=S1517-

$97022012000300013 \&$ Ing=en\&nrm=iso $>$. access on 04 June 2017.

MORAES, Roque. Análise de Conteúdo. Porto Alegre: Revista Educação, v.22, n.37, p.7-32, 1999. Disponível em:

http://cliente.argo.com.br/ mgos/analise de conteudo moraes.html. Acesso em 23-08-2012.

PEDRETTI, Erminia; NAZIR, Joanne. Currents in STSE education: Mapping a complex field, 40 years on. In: Science Education, 2011.

PIMENTA, Selma G. Apresentação à edição brasileira. In: CONTRERAS, José. A autonomia de professores. Tradução: Sandra Trabucco Valenzuela. São Paulo: Cortez, 2002, p.11-21.

PIOLLI, Alessandro L.; COSTA, Maria C. da. Public participation and rural management of brazilian Waters: an alternative to the deficit model. Journal of Science Communication, 7(4), 2008.

SANTOS, Wildson. Significados da educação científica com enfoque CTS. In: SANTOS, Wildson; AULER, Décio (Orgs.) CTS e educação científica: desafios, tendências e resultados de pesquisa. Brasília: Editora UnB, 2011, p.21-48.

SADLER, T.D.; ZEIDLER, D.L.Student conceptualizations of the nature of science in response to a socioscientific issue. INT. J. SCI. EDUC., 19 MARCH 2004, VOL. 26, NO. 4, 387-409

SELLI DECONTO, D. C.; CAVALCANTI, C. J. de H.; OSTERMANN, F. A perspectiva ciência, tecnologia e sociedade na formação inicial de professores de física: estudando concepções a partir de uma análise bakhtiniana. Alexandria: Revista de Educação em Ciência e Tecnologia, Florianópolis, v. 9, n. 2, p. 87-119, nov. 2016. ISSN 1982-5153. Disponível em: $<$ https://periodicos.ufsc.br/index.php/alexandria/article/view/19825153.2016v9n2p87>. Acesso em: 04 jun. 2017.

SOLOMON, Joshua. Teaching science, technology and society. Buckingham,U.K.: Open University Press. 1993.

SOMEKH, B.; BURMAN, E.; DELAMONT, S.; MEYER, J.; PAYNE, M.; THORPE, R. Pesquisa nas ciências sociais. In: SOMEKH, B.; LEWIN, C. (ORGS) TEORIA E MÉTODOS DE PESQUISA SOCIAL. Petrópolis, RJ: Vozes, 2015. 
VIEIRA, R.D.; BERNARDO, J.R.R.; EVEGOROU, M.; MELO, V.F. Argumentation in Sciencie Teacher Educatio: The simulatedjury as a resource for teaching and learning. International Journal of Science Education. April 2017.

Recebido: 04 jun. 2017

Aprovado: 16 jun. 2020

DOI: $10.3895 /$ rbect.v13n2.5971

Como citar: JUNIOR, A. F. T.; LOPES, N. C.; ABREU, A. H. S.; OLIVEIRA, C. R.; BRINA, D.; PIRES, H.; SILVA, R. P. Considerações sobre o trabalho com o júri simulado em uma questão sociocientífica com futuros professores de física. Revista Brasileira de Ensino de Ciência e Tecnologia, Ponta Grossa, v.13, n. 2, p. 127-159, mai./ago. 2020. Disponível em: <https://periodicos.utfpr.edu.br/rbect/article/view/5971>. Acesso em: XXX

Correspondência: Adenilson Francisco Tetzener Junior - adenilson.junior.qm@gmail.com

Direito autoral: Este artigo está licenciado sob os termos da Licença Creative Commons-Atribuição 4.0 Internacional.

\section{(c) (1)}

